Kinestetik : Jurnal Ilmiah Pendidikan Jasmani 5 (1) (2021)

Kinestetik : Jurnal Ilmiah Pendidikan Jasmani

https://ejournal.unib.ac.id/index.php/kinestetik/index

DOI : 10.33369/jk.v5i1.13591

\title{
HOMECOURT APPLICATION THROUGH ZOOM MEDIA TO IMPROVE STUDENT DRIBBLING TECHNIQUES IN HANDBALL COURSES IN PHYSICAL EDUCATION STUDY PROGRAM FKIP UNIB
}

\author{
Bogy Restu Ilahi $^{1^{*}}$, Defliyanto ${ }^{2}$, Syafrial $^{3}$ \\ ${ }^{123}$ Physical Education, Faculty of Teacher Training and Education, Universitas Bengkulu, \\ Bengkulu, Indonesia
}

\section{Article Info}

Article History :

Received : November 2020

Revised : January 2021

Accepted : March 2021

Available online : March 2021

Keywords:

Handball , Implementatin , Quality of learning

\begin{abstract}
This research is a Classroom Action Research in the scope of education carried out by lecturers, researchers in their class or together with other people.Increasing basic dribbling technique skills from before using the homecourt application method through online-based zoom media and after using the homecourt application method through zoom-based media. online in the precycle, it is proven that there has been no improvement because the homecourt application method has not been implemented. $40 \%$ of the 12 students who got complete scores with an average score of 67 out of 30 students. There was a significant increase in cycle II, there was an increase in dribbling skills in Handball games with the homecourt application method through online-based zoom media with 2 students who became guards. Evidenced by the results of research with an increase in completeness results to 19 students who completed with an average score in Handball learning of 72.25
\end{abstract}

ISSN 2685-6514 (Online)

ISSN 2477-331X (Print) 


\section{INTRODUCTION}

Education is a very important activity to prepare children for life in the future. Even the symptoms of the implementation process are still very simple. However, it is a phenomenon that the process will last a lifetime and we must develop it. Physical education is a learning process through physical activities designed to improve physical fitness, develop motor skills, knowledge, healthy behavior, active, sportsmanship, and emotional intelligence. (Triwijayanto, 2013)

In physical education, sports and health, there are three kinds of assessment aspects that will be developed, namely affective, cognitive, and psychomotor aspects. These three aspects are very much determined by an educator or teacher in learning physical education, sports, and health (Penjasorkes) starting from primary education, upper level, vocational level to higher education. From each level, students have different characteristics. So, in the implementation of learning a teacher must have good creativity so that the learning provided is in accordance with the learning abilities of students or students.

Handball is a sport that has been known in Indonesia for a long time, and is still one of the subjects taught at the Higher Education Education Institution (LPTK) for sports. Its existence is not taken into account due to several reasons, the types of games are less popular, lack of socialization, and do not have an official sports organization. As a sport, handball has several positive impacts on its players, including physical development, discipline, cooperation, social emotional, and life skills. This is certainly in accordance with the goals of national education in general. (Susanto, 2017)
Handball in Indonesia is experiencing a new phase after being unable to compete with the currently developing sports, at this time the community has begun to open up to new sports that are able to provide their own characteristics, especially those that are able to make the sport enjoyable to watch. In developing handball in Indonesia, of course, there must be support from all parties to be able to develop the sport of handball, this support is not only supported by all levels of society but must also be supported by various policy makers in the development of handball in Indonesia. In developing a new sport, of course, there are a lot of human resources that must be developed for the development of the sport, such as coaches, athletes and also development in terms of training. Development in terms of training in the handball sport, which in fact is a new sport, of course development in terms of training is very much needed to be able to improve handball achievement both from club level achievements and national and international persuasion.

The cross-season sport is a team game with the aim of getting more balls into the opponent's goal. The game of football is played using a ball that is thrown and caught with both hands on an indoor or outdoor court of a certain size. Handball is a team game that is done by throwing and catching the ball using the hand which aims to put the ball into the opponent's goal (Rochmat Rahayu, 2020). Likewise, the sport of handball can be traced to its historical truth and has a very old age. A convincing fact has shown that one played handball much earlier than football. The game of football played in ancient Greece is a sign of the creation of the modern handball sport (Susanto, 2017) 
The basic technique of dribbling is one of the basic techniques that must be mastered for sports that make teamwork more formal. According to dribling, dribling is one way of moving the ball from one place to another in order to build an attack. Things like this that must be mastered properly by each player in order to provide the best in the game with a very limited number of coaches, there is a need for development in terms of dribbling training to add coach references so that the training is more varied and not saturating.

Handball dribble is almost the same as basketball dribble, the difference is in the rules for dribbling the ball. Handball dribble uses two hands but in basketball dribble you can only use one hand and in basketball games players cannot carry the ball more than one step while in handball games players cannot carry the ball more than two steps. The handball training model, especially dribling, needs serious attention because in plain view it might look very easy to do but when we pay attention to this handball match it becomes a very serious problem, where we can see the basic technique of passing that is not being able to hit the target. desired so that the ball is thrown towards the opponent or out of the field. In carrying out passing exercises, of course, you must make the exercise as attractive as possible and make a passing training model that allows us to be in difficult conditions for passing so that with the development of passing practice it can improve basic passing techniques and make training more varied.

As for the problems that occur in the Physical Education Study Program which will be the place in this study, namely the implementation of learning that is less varied, meaning that learning is too monotonous without any new things that make students curious so that students are lazy during learning and there is less assignment of student skills. So far, students do not understand how to do dribble activities because they feel bored in doing learning that is too monotonous. Therefore, the author will conduct research by providing new methods and will make students enthusiastic in participating in handball dribble learning properly. Because with the HomeCourt application method that underlies the material to be taught, students can understand what will be explained. Thus, it is hoped that the provision of the HomeCourt Method related to handball dribbling in handball learning can be achieved.

The Undergraduate Physical Education Study Program, FKIP Unib, has one of the compulsory subjects, namely the Handball Organization course with a weight of 2 credits. This optional sport (Orpil) is given in odd semesters (III) with learning outcomes where students are able to know and understand and carry out handball sports properly and correctly. Handball itself has basic techniques that must be developed in order to create a quality game. The handball playing techniques are: Dribbling, Blocking, Catch, and Shooting. (Hermansah, 2018)

Dribbling is the skill of controlling and carrying the ball by bouncing it each time it hits the ground, with one or two hands. Dribbling is a fairly difficult skill because it requires high hand-eye coordination. Keep in mind that the direction the ball bounces will depend on the direction it is coming from the ball to the ground. Fast or slow movement of the ball comes from the strength and weakness of the ball. Throw (Susanto, 2017). Media is a component of learning resources or physical vehicles that contain instructional material in a learner's environment that 
can stimulate learners to learn. (Jennah, 2013)

Learning is an activity that involves someone in an effort to gain knowledge, skills and positive values by utilizing various sources for learning. Learning can involve two parties, namely students as learners and teachers as facilitators, the most important thing in learning activities is the learning process. (Rohani, 2019). Learning media includes all physical equipment and material used by instructors, lecturers, teachers, tutors, or other educators in carrying out learning and facilitating the achievement of learning objectives. The learning media in question includes traditional media consisting of chalk, handaouts, diagrams, slides, overheads, real objects, and video recordings, or advanced films and media such as computers, DVDs, CD-ROMs, the Internet, interactive video conferencing and so on. (Yaumi, 2017)

The use of instructional media in the teaching and learning process can generate new interests and desires, generate motivation and stimulation of learning activities, and even bring psychological influences on students. The use of learning media at the teaching orientation stage will greatly help the effectiveness of the learning process and the delivery of messages and lesson content at that time (Hayes et al., 2017)

The sudden COVID-19 pandemic requires an educational element to sustain online learning. The current condition is urgent to make innovations and adaptations related to the use of available technology to support the learning process (Herliandry et al., 2020). One form of appeal in the education sector is a change in the parallel learning process, which was originally carried out offline (outside the network) to online (online). (Suci, 2020)
Online learning is learning that uses internet networks with accessibility, connectivity, flexibility, and the ability to generate various types of learning interactions. (Firman \& Rahayu, 2020). Various platforms can be used to support online learning, it is stated that online learning is an alternative to face-to-face lecture curricula (Darmalaksana et al., 2020). In observing handball learning, it can be seen that most students of the Physical Education Study Program FKIP UNIB are still unfamiliar with the science of handball. In addition, some students tended to emphasize more on scoring activities rather than implementing quality games through the application of handball playing exercises.

This is of course worrying because the main objective of this handball course is for students to be able to play handball well in order to create a quality game. However, the facts that occur during the observation show that most of the students of the FKIP Unib Physical Education Study Program tend to lose during handball matches and do dribling. This shows that the basic technique of handball that students have tends to be weak, especially when the Covid-19 pandemic that is being felt at this time has to isolate themselves at home by doing Physical Distance (Keep Distance) with hesitation time.

The Homecourt application is an online application that stimulates students to move according to programmed instructions and is able to create or make movements to be practiced or learned. Furthermore, the use of the Homecourt application as a learning method can be effectively used in handball training during the Covid-19 pandemic which requires Stay At Home.

This method requires students to learn the correct video module and basic dribbling techniques first through zoom 
media, after which students learn the Homecourt program that has been downloaded on Playstore and carry out trials individually but still in accordance with predetermined rules. Through the Homecourt application which is applied to handball subjects, researchers hope that there will be an increase in the quality of practical learning in handball subjects so that students' abilities increase and the desired results in learning are achieved.

\section{METHODS}

The research method is the method used by researchers in collecting research data (W,Gulo 2013) This research is a Classroom Action Research, which is classroom action research in the scope of education carried out by lecturers, as well as researchers in their class or together with other people (collaboration) by designing, implementing, and reflecting on collaborative and participatory actions. which aims to improve or improve the quality (quality) of the learning process in the classroom through certain actions (treatment) in one cycle (Widayati, 2014)

This study uses a descriptive method because in this study it describes the extent to which the quality of learning has been improved by using the Homecourt application for students who are the research sample. The application of this learning application to the Handball subject allows students to have an increase in quality in handball games so that Bolatanga learning gets the desired results in learning.

\section{Place and time of research}

This research was conducted at Bengkulu University in semester III-A students of the Physical Education Study Program FKIP UNIB who took the
Handball course. The research time was carried out in the odd semester of the 2020/2021 school year from June to November 2020

\section{Population and Research Sample}

The subjects of this study were researchers who acted as handball lecturers and 30 students who took these courses. (Prof. dr. sugiyono, 2013) The population of this study was all students of the Physical Education Study Program FKIP UNIB in the academic year 2020/2021. While the sample in this study were students of semester III-A Physical Education Study Program FKIP UNIB who were taking handball courses.

\section{Procedure}

This classroom action research plan will be carried out by carrying out one cycle until there is an increase in the learning of handball subjects, and each cycle consists of four stages, namely (1) the planning stage, (2) action, (3) observation. (observing), and (4) reflection (reflection). (Prof. dr. sugiyono, 2013)

\section{Data Design or Analysis}

The data analysis technique used in this research is descriptive statistics, namely in the form of percentages presented in tables or graphs. Categories in the data will be adjusted according to the existing percentage.(Gulo, 2013) The following formulas will be used in data processing.

$$
X=\frac{€ X}{€ X m a k s} \quad x 100 \%
$$

Information ;

$\mathrm{X}=$ the value you are looking for is in percent

$€ X=$ Total student scores,

$€ X \max =$ The sum of the total score 


\section{RESULTS}

Discussion and Conclusion The results showed that there was an increase in the basic skills of handball dribbling through the homecourt application through the zoom media to test the basic techniques of handball dribbling. Overall the results of the study show an increase as in the following graph

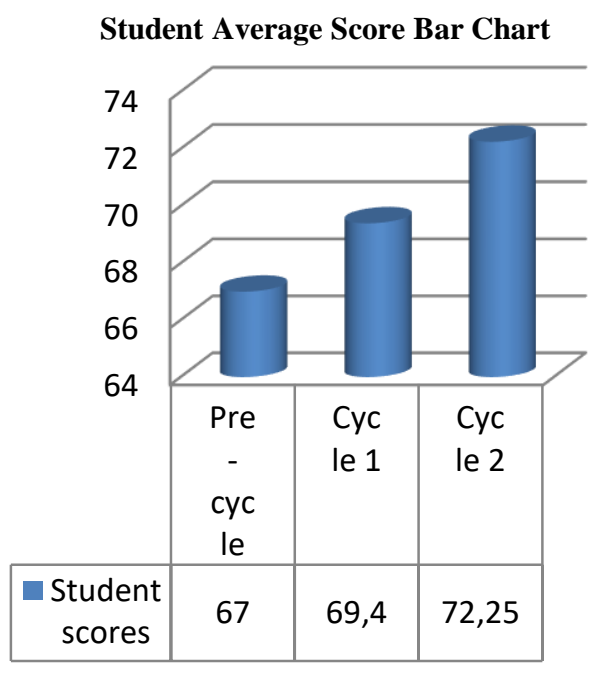

Figure 1. Average Value Per Cycle

\section{CONCLUSION}

Based on the research data that has been obtained and the results of data calculation, it can be concluded as follows:

1.Improvement of basic dribbling technical skills from before using the homecourt application method through online-based zoom media and after using the homecourt application method through online-based zoom media in the pre-cycle, it is evident that there has been no improvement because the Homecourt application method has not been applied from $40 \%$ of 12 students who obtaining completeness scores with an average score of 67 out of a total of 30 students.
2.There was an increase in the first cycle which was proven to increase from 53\% of the 16 students who obtained completeness scores from a total of 30 students who used the homecourt application method through online-based zoom media. There was an increase in the pre-cycle, namely an increase of $13 \%$ with completeness from 12 students to 16 students who completed with an average score of 69.4 in Handball learning.

3. In the second cycle there was an increase in dribbling skills in the Handball game with the homecourt application method through online-based zoom media with 2 students who became guards. Evidenced by the results of research with an increase in completeness results of $63 \%$ from cycle I which only $53 \%$ complete from 30 students. There was an increase from cycle I, namely an increase of $10 \%$ with completeness from 16 students to 19 students who completed with an average score in Handball learning of 72.25.

\section{SUGGESTION}

1. For further research, it is hoped that in the application of the homecourt application method through online-based zoom media on Orpil Handball, it is hoped that the lecturers can develop the homecourt application method through online-based zoom media to be even better with some additional modifications so that Handball learning about basic dribbling techniques can be maximized, especially in virtual and online learning.

2. Lecturers can use the homecourt application method through online-based zoom media on other subjects in the form of games in the field. 


\section{REFERENCES}

Darmalaksana, W., Hambali, R. Y. A., Masrur, A., \& Muhlas. (2020). Analisis Pembelajaran Online Masa WFH Pandemic Covid-19 sebagai Tantangan Pemimpin Digital Abad 21. Karya Tulis Ilmiah (KTI) Masa Work From Home (WFH) Covid-19 UIN Sunan Gunung Djati Bandung Tahun 2020, $1(1), 1-12$.

Firman, F., \& Rahayu, S. (2020). Pembelajaran Online di Tengah Pandemi Covid-19. Indonesian Journal of Educational Science (IJES), 2(2), 81-89.

https://doi.org/10.31605/ijes.v2i2.659

Gulo, w. (2013). Metodologi Penelitian.

Hayes, C., Hardian, H., \& Sumekar, T. (2017). Pengaruh Brain Training Terhadap Tingkat Inteligensia Pada Kelompok Usia Dewasa Muda. Diponegoro Medical Journal (Jurnal Kedokteran Diponegoro), 6(2), 402416.

Herliandry, L. D., Nurhasanah, N., Suban, M. E., \& Kuswanto, H. (2020). Pembelajaran Pada Masa Pandemi Covid-19. JTP - Jurnal Teknologi Pendidikan, 22(1), 65-70. https://doi.org/10.21009/jtp.v22i1.1528 6

Hermansah, B. (2018). Modifikasi Permainan Bola Tangan Terhadap Hasil Belajar Passing Dalam Pembelajaran Bola Tangan Mahasiswa. Wahana Didaktika, 16(1), 35-41.

Jennah, R. (2013). Media Pembelajaran. In digilib.iain-palangkaraya.ac.id.

Prof. dr. sugiyono. (2013). Prof. dr. sugiyono, metode penelitian kuantitatif kualitatif dan r\&d.

Rochmat Rahayu, T. S. \& D. B. (2020). Implementasi Model Pembelajaran Pada Olahraga Permainan Bolatangan. PHYSICAL ACTIVITY JOURNAL, 1 Nomor 22.

Rohani. (2019). Diktat Media Pembelajaran. Fakultas Ilmu Tarbiyah Dan Keguruan Universitas Islam Negeri Sumatera Utara, 95.

Suci, M. P. (2020). Efektivitas Pembelajaran
Berbasis Daring Pada Mata Kuliah Insya' Di Stai Ma'Arif Sarolangun. Pendidikan Bahasa Dan Sastra Arab, 1(2), 59-68.

Susanto, E. (2017). Pengembangan tes keterampilan dasar olahraga bola tangan bagi mahasiswa. Jurnal Penelitian Dan Evaluasi Pendidikan, 21(1), 116-125. https://doi.org/10.21831/pep.v21i1.157 84

Triwijayanto, N. K. (2013). Model Pengembangan Permainan Bola Tangan "Kappar" Dalam Penjasorkes Pada Siswa Kelas V Sdn Muntung Kecamatan Candiroto Kabupaten Temanggung Tahun 2012. In Active Journal of Physical Education, Sport, Health and Recreation (Vol. 2, Issue 5). https://doi.org/10.15294/active.v2i5.12 22

Widayati, A. (2014). Penelitian Tindakan Kelas. Jurnal Pendidikan Akuntansi Indonesia, 6(1). https://doi.org/10.21831/jpai.v6i1.1793 Yaumi, M. (2017). Media Pembelajaran, pengertia, Fungsi dan Tujuan. Repositori.Uin-Alauddin, 4, 9-15. 